University of Wollongong

Research Online

Faculty of Business - Papers (Archive)

Faculty of Business and Law

2014

Stakeholders' power, corporate characteristics, and social and environmental disclosure: evidence from China

Yingjun Lu

Shanghai University of International Business and Economics

Indra Abeysekera

University of Wollongong, indraa@uow.edu.au

Follow this and additional works at: https://ro.uow.edu.au/buspapers

Part of the Business Commons

Research Online is the open access institutional repository for the University of Wollongong. For further information contact the UOW Library: research-pubs@uow.edu.au 


\title{
Stakeholders' power, corporate characteristics, and social and environmental disclosure: evidence from China
}

\author{
Abstract \\ This paper investigates the influences of stakeholders' power and corporate characteristics on social and \\ environmental disclosure practices of socially responsible Chinese listed firms identified by a social \\ responsibility ranking list. A stakeholder-driven, three-dimensional social and environmental disclosure \\ index including disclosure quantity, disclosure type quality and disclosure item quality, is constructed to \\ assess sample firms' social and environmental disclosures in their two public reports: annual reports and \\ corporate social responsibility reports. Findings indicate that corporate social and environmental \\ disclosures have significant and positive associations with firm size, profitability, and industry \\ classification. The roles of various powerful stakeholders in influencing corporate social and \\ environmental disclosures are found to be generally weak in China, except that shareholders have \\ influenced corporate social and environmental disclosures and creditors have influenced corporate \\ disclosures related to firms' environmental performance.
}

\section{Keywords}

characteristics, social, environmental, china, disclosure, evidence, stakeholders, power, corporate

Disciplines

Business

\section{Publication Details}

Lu, Y. \& Abeysekera, I. (2014). Stakeholders' power, corporate characteristics, and social and environmental disclosure: evidence from China. Journal of Cleaner Production, 64, 426-436. 
Lu, Y. \& Abeysekera, I. 2014, Stakeholders' power, corporate characteristics, and social and environmental disclosure, Journal of Cleaner Production, Vol. 64, No.1, pp. 426-436.

Stakeholders Power, Corporate Characteristics and Social and Environmental Disclosure

\title{
: Evidence from China
}

\author{
Yingjun Lu
}

Shanghai University of International Business and Economics, China

Indra Abeysekera

University of Wollongong, Australia 


\title{
Stakeholders' Power, Corporate Characteristics, and Social and Environmental Disclosure \\ : evidence from China
}

\begin{abstract}
This paper investigates the influences of stakeholders' power and corporate characteristics on social and environmental disclosure practices of socially responsible Chinese listed firms identified by a social responsibility ranking list. A stakeholder-driven, three-dimensional social and environmental disclosure index including disclosure quantity, disclosure type quality and disclosure item quality, is constructed to assess sample firms' social and environmental disclosures in their two public reports: annual reports and corporate social responsibility reports. Findings indicate that corporate social and environmental disclosures have significant and positive associations with firm size, profitability, and industry classification. The roles of various powerful stakeholders in influencing corporate social and environmental disclosures are found to be generally weak in China, except that shareholders have influenced corporate social and environmental disclosures and creditors have influenced corporate disclosures related to firms' environmental performance.
\end{abstract}

Keywords: China, Social and environmental disclosure, Social and environmental disclosure index, Stakeholder, Legitimacy, Corporate social responsibility. 


\section{Introduction}

Over the past three decades, China has made great achievements in its economic development by transforming from a central planned economy to a market-oriented one, establishing capital markets, and attracting substantial foreign direct investment, which has resulted in China's carving out a place in the globalized market. However, along with the rapid economic growth, a number of serious social and environmental issues have arisen, including environmental pollution, energy shortages, occupational diseases and death, and an absence of product responsibility. For instance, dangerous working conditions and occupational diseases and injuries in mining and labor-intensive manufacturing industries are often reported in both Chinese and foreign media (UNESCAP, 2010; World Bank, 2004). In particular, in 2008, with the news that milk powder exported from some Chinese firms was declared poisonous to human health, at least 25 countries stopped all imports of Chinese dairy products (UNESCAP, 2010). Events such as this serious social reputation crisis have made corporate social responsibility (CSR) a priority for the Chinese government, and an essential tool to ensure and propel China's economic growth.

Facing these social and environmental issues, the Chinese government has made sustainable development a national strategy to ensure continuous economic growth, and has made efforts to encourage Chinese firms to become more socially and environmentally responsible to their stakeholders. Social and environmental disclosure is a relatively new practice for Chinese firms. Prior to 2005, a very limited number of Chinese firms disclosed social and environmental information in their annual reports or social and environmental reports (including environmental reports, CSR reports, or sustainability reports). In early 
2008, China's State-owned Assets Supervision and Administration Commission of the State Council (SASAC) issued recommendations to guide social responsibility activities of central state-owned enterprises (SOEs) (SASAC, 2008). In response to the Chinese government's efforts to highlight sustainable development, both the Shenzhen Stock Exchange (SZSE) and the Shanghai Stock Exchange (SSE) promulgated social responsibility guidelines for listed firms in 2006 and 2008 respectively, to encourage listed firms to publicly disclose social and environmental information in their annual reports or CSR reports. Consequently, increasing Chinese listed firms began to publish CSR reports or sustainability reports as supplementary reports to annual reports. All these governmental efforts and relevant agencies' initiatives highlighted the sudden surge in corporate social and environmental disclosure in China. According to the SSE, in 2008, 290 firms out of about 980 firms listed on the SSE published CSR reports in addition to their annual reports, and of these, 282 firms published them for the first time (China Securities Journal, 2009). With the Chinese communities' concerns on social and environmental issues, an independent rating agency initiated by Southern Weekend (one of China's most popular newspapers), consisting of a group of experts and scholars from the government, industries, universities, and research institutes, has taken the initiative to rank Chinese listed firms in terms of their social responsibility levels in 2008.

Corporate social and environmental disclosure as a dialogue between firms and their stakeholders who are interested in corporate social and environmental activities, demonstrates the fulfillment of corporate social responsibility to their stakeholders. Some of these stakeholders have the power to influence managerial decisions to disclose social and environmental information, and past studies have demonstrated that decisions to 
disclose are also influenced by corporate characteristics (Liu and Anbumozhi, 2009; Roberts, 1992; Unerman, 2007). It is in that light that this study aims to examine the influences of stakeholders' power and corporate characteristics on corporate social and environmental disclosure in the Chinese context. This study extends the literature in following ways. First, it examines corporate social and environmental disclosure practices from stakeholders' rather than firms' or researchers' perspectives. It does so by constructing a stakeholder-driven, three-dimensional social and environmental disclosure index that integrates the disclosure quantity and two aspects of the disclosure quality perceived by stakeholders. Secondly, it combines two theoretical underpinnings, legitimacy and stakeholder, to construct and examine empirical variables, acknowledging that two frameworks rather than one provide more meaningful insights in understanding social and environmental disclosure from stakeholders' perspectives. Thirdly, considering that corporate social and environmental disclosure is a relatively new, underdeveloped, but somewhat regulated phenomenon in China, this study examines the socially responsible firms to obtain 'best disclosure practice' insights into the Chinese context.

To achieve the above research objectives, a joint theoretical framework of legitimacy theory and stakeholder theory was developed. The proposed hypotheses were then tested by using the data generated through content analysis of reports, evaluating stakeholders' perspectives from questionnaire survey and panel consultation, developing a social and environmental disclosure index, and applying ordinary least squares regression to evaluate the association between stakeholders' power, corporate characteristics and disclosures. The conclusions indicate that corporate characteristics (firm size, profitability, and industry 
classification) have statistically significant associations with corporate social and environmental disclosure. Findings also indicate that stakeholders generally have weak powers in influencing corporate social and environmental disclosure, although shareholders have influenced corporate social and environmental disclosure and creditors have influenced corporate disclosures related to their environmental performance.

The remainder of this paper is organized as follows. Section 2 reviews the literature related to corporate social and environmental disclosure. Section 3 explains the theoretical framework and develops relevant hypotheses. Section 4 describes the sample and research methods used in this study. Section 5 presents the empirical results and analyses, and Section 6 provides conclusions.

\section{Literature review}

The social and environmental disclosure literature has accumulated a number of studies examining the determinants of disclosure (Branco and Rodrigues, 2008; Cormier and Gordon, 2001; Garcia-Sanchez et al., 2013; Hackston and Milne, 1996; Roberts, 1992). Corporate characteristics of disclosure typically examined in the literature include firm size, profitability, industry classification, country of origin, and firm age. Although some determinants have been repeatedly identified, the findings from prior studies are mixed. As to firm size, several studies suggest that large firms made more social and environmental disclosure than small firms (Choi, 1999; Cormier and Gordon, 2001; Hackston and Milne, 1996; Mahadeo et al., 2011), whereas Roberts (1992) found no relationship between firm 
size and the level of corporate social and environmental disclosure. Likewise, several empirical studies have found that industry classification does appear to affect corporate social and environmental disclosure (Branco and Rodrigues, 2008; Choi, 1999; Hackston and Milne, 1996) but the studies are not clear or consistent enough to determine directional effects with precision (Gray et al., 1995). Empirical findings on the profitability and disclosure relationship are also mixed, with some studies failing to find any relationship between profitability and corporate social and environmental disclosure (Hackston and Milne, 1996; Patten, 1991), others finding a negative relationship (Neu et al., 1998), and still others finding a positive relationship (Cormier and Magnan, 1999, 2003; Roberts, 1992).

Stakeholders' powers include influences exerted by various stakeholder groups on firms, and these stakeholder groups are typically shareholder, creditor, government, and special interest groups (Choi, 1999; Cormier and Magnan, 2003; Garcia-Sanchez et al., 2013; Roberts, 1992). The findings of previous studies have indicated that corporate social and environmental disclosure is associated with various stakeholder groups: shareholders (Cormier and Magnan, 2003; Deegan and Rankin, 1997), creditors (Choi, 1999; Roberts, 1992), governmental influence (Garcia-Sanchez et al., 2013; Roberts, 1992), and special interest groups (Deegan and Blomquist, 2006; Deegan and Rankin, 1997).

Most of the previous studies in the literature were conducted in developed countries, and there is a shortage of studies focused on developing countries and China in particular. Even the extant literature focused on the Chinese context is mostly descriptive (Guo, 2005; Xiao 
and $\mathrm{Hu}, 2005$ ) and fails to provide an in-depth analysis of the determinants (corporate characteristics and stakeholders' power) and their associations with firms' disclosures. Two exceptions are Liu and Anbumozi (2009) and Zeng et al. (2010). Zeng et al. (2010) examined the status of environmental disclosures of 871 listed manufacturing firms in China, and found that industrial sector, firm size, and ownership are determinants of corporate environmental disclosure. Liu and Anbumozhi (2009) examined the determinants affecting environmental disclosures of Chinese listed firms and found that firms' environmental sensitivity and firm size are significantly and positively associated with environmental disclosure, and theorized their findings under stakeholder theory.

Unlike previous studies both in Western and Chinese contexts, this study measures corporate social and environmental disclosure from the stakeholders' perspectives rather than the researchers' perspectives. A stakeholder-driven, three-dimensional social and environmental disclosure index that integrates the disclosure quantity and two aspects of the disclosure quality is constructed to measure corporate social and environmental disclosure. The two aspects of disclosure quality (i.e., disclosure type quality and disclosure item quality) in the index are approached by surveying stakeholders to obtain their perceptions about disclosure type preference (i.e., narrative and various quantified disclosures) and disclosure item importance (i.e., GRI items). This study then investigates stakeholders' powers as determinants of social and environmental disclosure as perceived by stakeholders, controlling for corporate characteristics that previous studies have determined to influence such disclosure. This investigation is undertaken with Chinese socially responsible firms as they are considered to have a strong stakeholder focus. 


\section{Theoretical framework and research hypotheses}

\subsection{A joint framework of legitimacy theory and stakeholder theory}

Legitimacy theory attempts to explain why a firm makes social and environmental disclosure, and argues that a firm is legitimized when its value system matches that of the social system of which it forms a part, and that the legitimacy is threatened when the firm's value system does not match that of the social system (Lindblom, 1994). Legitimacy therefore becomes a resource that a firm can create, influence, or manipulate through various disclosure-related strategies (Woodward et al., 2001). A firm may be motivated to disclose social and environmental information to legitimize its status within society (Deegan, 2002). The disclosure-related strategy may be either proactive for a firm to gain or maintain the support of the general public and particular interest groups (O'Donovan, 2002; Van Staden and Hooks, 2007) or reactive for the firm to repair its legitimacy threats (Cho, 2009; Deegan et al., 2002). Whilst legitimacy theory focuses upon the expectations of society in general, stakeholder theory focuses upon the expectations of particular interest groups.

In the context of a firm, society can be grouped as shareholders, creditors, employees, customers, and suppliers, who may be interested in the firm's social and environmental activities. Freeman (1984) identified these groups as "stakeholders." Stakeholders differ in the nature and the level of influence they exercise on a firm's activities. The nature and the level of influence are manifested as stakeholders' powers and they have the capacity to influence managerial strategic decisions in the form of control over resources required for 
the firm to continue to exist (Ullmann, 1985). Corporate social and environmental disclosure is expected to be an effective management strategy for developing and maintaining satisfactory relationships with powerful stakeholders. Stakeholder theory attempts to explain how a firm identifies those powerful stakeholder groups who may affect, or be affected by, the firm's social and environmental disclosure practices, and how the firm responds to their expectations.

Legitimacy theory (as a form of social dynamics) and stakeholder theory (powerful stakeholders within the social dynamics) are better seen as two overlapping perspectives that provide different and useful points of view. It is possible and helpful to jointly consider them to provide more insightful explanations for corporate social and environmental disclosure practices. A few previous studies on Chinese firms' social and/or environmental disclosure have discussed the application of legitimacy theory and/or stakeholder theory in the Chinese context (Liu and Anbumozhi, 2009; Taylor and Shan, 2007).

\subsection{Hypotheses}

In line with the above discussion, empirical tests in this study consider the influence of four stakeholder groups (i.e., government, shareholder, creditor, and auditor) on corporate social and environmental disclosure. Neu et al. (1998) provided support for the view that particular stakeholder groups can be more effective in demanding corporate social and environmental disclosure, such as shareholders and government regulators. Prior studies have established various relationships between corporate characteristics (i.e., firm size, 
profitability, industry classification, and overseas listing) and corporate social and environmental disclosure. Those studies suggest that firms with prominent corporate characteristics are more likely to be scrutinized by the society, which increases the necessity to match their values with that of the society (Neu et al., 1998; Patten, 1991). Hence, firms with prominent corporate characteristics are more likely to make social and environmental disclosures (Deegan, 2002). However, the influences of corporate characteristics on social and environmental disclosure are sparsely examined in the Chinese context, and this study therefore tests their empirical validity in addition to the influence of stakeholders' power. Based on the joint consideration of legitimacy and stakeholder theories, a number of hypotheses are proposed as outlined in the section that follows (please see Figure 1 for a summary). 


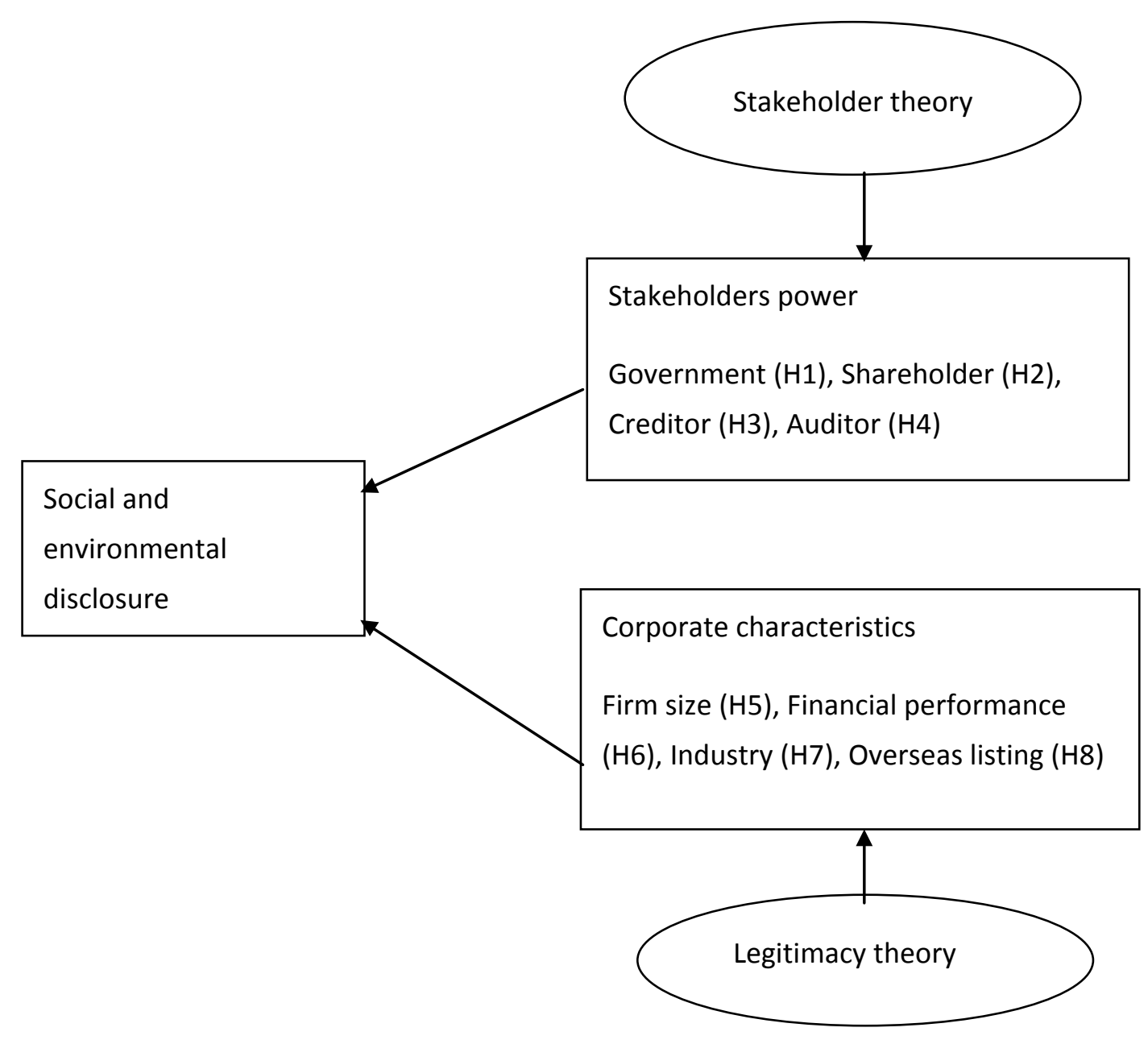

Fig. 1. The relationship between social and environmental disclosure and various determinants

\subsubsection{Stakeholders' power}

\section{Government power}

Roberts (1992) provided empirical evidence to support Freeman's (1984) stakeholder perspective, which recognizes the ability of the government to influence corporate strategy and performance via regulations. Liu and Anbumozhi (2009) found that the Chinese government had positive and significant influence on environmental disclosures of Chinese 
listed firms. The introduction of recommendations to guide social responsibility activities of central state-owned enterprises (SOEs) by the State-owned Assets Supervision and Administration Commission of the State Council (SASAC) is a further confirmation of the government's regulatory power on Chinese firms' social and environmental disclosures. We therefore expect that central SOEs use corporate social and environmental disclosure as a strategic tool to satisfy the demand of this powerful stakeholder, the government. For this reason, it is hypothesized that:

H1: There is a positive association between government power and corporate social and environmental disclosure.

\section{Shareholder power}

Previous studies have examined the power of shareholders to influence corporate social and environmental disclosure (Choi, 1999; Liu and Anbumozhi, 2009; Roberts, 1992). Keim (1978) stated that as the distribution of ownership of a firm becomes less concentrated, the demands placed on the firm by shareholders become broader. The less concentrated ownership encourages the management to disclose more relevant information to meet various shareholders' demands. Disperse corporate ownership increases pressure for management to disclose social responsibility information (Ullmann, 1985). It is therefore hypothesized that:

H2: There is a negative association between concentrated ownership and corporate social and environmental disclosure. 


\section{Creditor power}

Creditors as providers of loan capital are powerful stakeholders who can influence firms' activities and disclosures. Roberts (1992) argued that the greater the degree to which a firm relies on debt financing, the greater the degree to which corporate management would be expected to respond to creditors' expectations concerning the firm's role in socially responsible activities. Empirical evidence on the relationship between creditor and disclosure is, however, contradictory (Cormier and Magnan, 1999, 2003). Cormier and Magnan (2003) found a negative association between financial leverage and disclosure, arguing that only firms that are financially sound (low leverage) may be able to trade off the benefits from social and environmental disclosure against the proprietary costs of revealing them. Findings also point out that firms with low leverage are more likely to engage in corporate social and environmental disclosure to ensure proper assessment of their financial risk by market participants. Considering mixed findings from prior studies, this study re-examines the effects of creditors on corporate social and environmental disclosure in the context of socially responsible listed firms in China, to identify the directional effect of the creditor power on corporate social and environmental disclosure, and therefore the non-directional hypothesis is stated as follows:

H3: There is an association between corporate financial leverage and corporate social and environmental disclosure.

\section{Auditor power}


Auditors are professionally influential in guiding their clients in initiating and promoting new accounting practices (e.g., social responsibility accounting). Society tends to perceive that larger audit firms such as Big Four are fairer and more impartial in their audit opinions as they are less likely to be affected by their client firms (Choi, 1999) and therefore are more likely to exercise the auditor's independence (DeAngelo, 1981). Further, larger audit firms have greater expertise and experience in influencing firms to disclose additional information (Wallace et al., 1994). For instance, Craswell and Taylor (1992) found a positive association between auditor and voluntary reserve disclosure in the Australian oil and gas industry. In a Malaysian study, Ahmad et al. (2003) also found that firms audited by Big-5 auditors disclosed more environmental information in their annual reports. To test the relationship between auditor power and corporate social and environmental disclosure, this study proposes the following hypothesis:

H4: There is a positive association between financial audits by the Big Four and corporate social and environmental disclosure.

\subsubsection{Corporate characteristics}

Firm size

Larger firms are more likely to be subject to public scrutiny, and therefore will disclose more information to obtain public support for their continuing existence (Cormier and Gordon, 2001). Larger firms have more shareholders who may be interested in corporate social activities and are more likely to use disclosure to communicate results of corporate social endeavors (Cowen et al., 1987). Firm size has been found to be a strong indicator of 
influencing corporate social and environmental disclosures (Choi, 1999; Cormier and Gordon, 2001; Hackston and Milne, 1996; Liu and Anbumozhi, 2009). Therefore, this study proposes the following hypothesis:

H5: There is a positive association between firm size and corporate social and environmental disclosure.

Financial performance

As Ullmann (1985) argued, economic performance can influence corporate financial capability to undertake costly programs related to social demands. Highly profitable firms are seemingly more credible to the public, which raises societal expectations of accountability. These firms were found to be more quickly to resolve social and environmental issues that they encounter (Cormier and Magnan, 1999). Previous studies support a positive association between corporate financial performance and corporate social and environmental disclosure (Cormier and Magnan, 1999, 2003; Roberts, 1992), and therefore it is hypothesized that:

H6: There is a positive association between corporate profitability and corporate social and environmental disclosure.

Industry

The greater visibility of an industry sector may drive disclosure as firms seek to avoid undue pressure and criticism from social activists (Patten, 1991). Different industries have different 
characteristics that are shaped by the intensity of competition, consumer visibility, and regulatory risk (Roberts, 1992). These different characteristics can influence corporate social and environmental disclosure and hence disclosure is industry-specific. For example, Dierkes and Preston (1977) found that firms in the extractive industry are more likely to disclose information about their environmental impacts than are firms in other industries. Some empirical studies have classified industries into high-profile and low-profile based on some traits of industry (e.g., consumer visibility, regulatory risk, and the intensity of competition), and have documented a positive association between such an industry classification and corporate social and environmental disclosure (Hackston and Milne, 1996; Roberts, 1992). For example, Roberts (1992) demonstrated that high-profile industries (i.e., high consumer visibility, high regulatory risk, or concentrated intense competition) are more likely to make greater levels of social responsibility disclosures. In this study, we also classify industries into high- and low-profile categories as previous studies indicate that high-profile industry sectors are likely to make more social and environmental disclosure (Roberts, 1992; Hackston and Milne, 1996), and hypothesize that:

H7: There is a positive association between industry classification and corporate social and environmental disclosure.

\section{Overseas listing}

Firms whose shares are cross-listed on other developed stock markets can face additional social and environmental regulations and disclosure requirements (Gray et al, 1995; Hackston and Milne, 1996). Consequently, firms with overseas listings may disclose more 
social and environmental information to the public to legitimize their operations (Hackston and Milne, 1996). To test this, the following hypothesis is proposed:

H8: There is a positive association between overseas listing and corporate social and environmental disclosure.

\section{Research methods}

\subsection{Sample and data}

The sample of this study comprises the full 100 firms in the 2008 Chinese Stock-listed Firms' Social Responsibility Ranking List. This ranking list is initiated by Southern Weekend (one of China's most popular newspapers), and co-investigated by the All-China Federation of Trade Unions, All-China Federation of Industry \& Commerce, Peking University, Fudan University, and Nankai University. It is the first corporate social responsibility rating system in China. The sample firms, summarized and grouped according to industry sector, are presented in Table 1. 
Table 1

Distribution of Sample firms

\begin{tabular}{|l|c|}
\hline Industry sector & No. of firms \\
\hline High profile a/ & 28 \\
\hline Metals \& non-metallic & 12 \\
\hline Banking \& insurance & 10 \\
\hline Extractive & 7 \\
\hline Construction & 4 \\
\hline Telecommunication & 3 \\
\hline Electricity, gas, and water production and supply & 3 \\
\hline Transportation \& warehousing & 2 \\
\hline Oil, chemical, and plastic & 2 \\
\hline Food \& beverage & 3 \\
\hline Low profile a/ & 3 \\
\hline Machinery, equipment, and instrumentation & 4 \\
\hline Electronics & 3 \\
\hline Wholesale \& retail trade & \\
\hline Information technology & \\
\hline Conglomerate & \\
\hline Real estate & \\
\hline Total & \\
\hline
\end{tabular}

a/ Note: The Regulations of Environmental Inspection on Companies Assessing to or Refinancing on the Stock Market (SEPA, 2003) stipulates that the following industries are pollution industries: metal, extractive, construction, electricity, oil and chemical, food and beverage. In China, the following industries are viewed with high consumer visibility: banking and insurance, telecommunication, and transportation. All the pollution industries and high consumer visibility industries are high-profile industries. 
Sample firms' 2008 annual reports and corporate social responsibility (CSR) reports were used as the data source for collecting corporate social and environmental disclosure data in this study. The annual report is widely viewed as the principal means for corporate communication to the public about the firm's activities (Wiseman, 1982), and has been the source for almost all previous social and environmental disclosure studies. The use of sources other than the annual report, such as stand-alone environmental reports or CSR reports, is also found in the existing literature (Clarkson et al., 2008; Cormier et al., 2004). We used both annual reports and CSR reports as it is likely that stakeholders consider all publicly available reports in their decision-making (Van Staden and Hooks, 2007). The relevant financial data of sample firms for the year 2008 were collected from the China Stock Market and Accounting Research (CSMAR) database.

\subsection{A three-dimensional social and environmental disclosure index (SEDI)}

Recent studies have investigated corporate social and environmental disclosures based on widely accepted reporting frameworks, such as the Global Reporting Initiative (GRI) Sustainability Reporting Guidelines (Clarkson et al., 2008; Frost et al., 2005). The standard disclosures of the GRI Guidelines (G3.0 version) were adopted to codify sample firms' annual reports and CSR reports in this study. The GRI reporting framework generally comprises two broad parts: the overall context for understanding organizational performance (i.e., Strategy and Analysis, Organizational Profile, Report Parameters, and Governance, Commitments, and Engagement), and organizational performance indicators (i.e., Economic Performance [EC], Environmental Performance [EN], and Social Performance including Labor Practices [LA], Human Rights [HR], Society [SO], and Product Responsibility 
$[P R])$, totally containing 121 reporting items (GRI, 2006). As outlined in Figure 2, a social and environmental disclosure index (SEDI) was constructed by integrating the importance of reporting items ascertained by stakeholders, the preference of different disclosure types ascertained by stakeholders, and the quantity of disclosure in annual reports and CSR reports.

\subsubsection{Disclosure quantity}

We measured the disclosure quantity by counting how frequently firms disclosed each of the 121 items in their annual reports and CSR reports. We used the definitions offered in the GRI framework for each disclosure item to guide the coding of annual reports and CSR reports. Corporate social and environmental disclosures were identified by the 'meaning' implied in the text according to the definition of each GRI item, and were counted by the number of times that each item was mentioned in the annual report and the CSR report. This latent content analysis enabled us to capture disclosure items more comprehensively than by a manifest content analysis technique such as searching for pre-determined words in annual reports and CSR reports.

\subsubsection{Disclosure type quality}

In previous studies, the quality of social and environmental disclosure was assessed by researchers to assign an ordinal value to different disclosure types (Choi, 1999; Clarkson et al., 2008; Toms, 2002; Wiseman, 1982). Researchers' judgment may not necessarily align with stakeholders' judgment on the disclosure quality. Therefore, this study consulted 
stakeholders to obtain their perceptions about disclosure types preference and disclosure items importance. We ascertained stakeholders' perceptions about disclosure types by conducting a questionnaire survey.

Based on the literature (Clarkson et al., 2008; Toms, 2002), we identified five disclosure types: (1) general narrative; (2) specific endeavor in non-quantitative terms; (3) quantified performance data; (4) quantified performance data relative to benchmarks (e.g., targets, industry, previous periods); and (5) quantified performance data at disaggregate level (e.g., plant, business unit, geographic segment). The questionnaire adopted a continuous rating scale where stakeholders were asked to rate the relative importance of five disclosure types by placing a mark at the appropriate position on a continuous line between two fixed points 0 and 100 (Brace, 2004).

As corporate stakeholders include a wide range of various interest groups and different stakeholder groups focus on different categories of corporate social and environmental disclosures, we surveyed given stakeholder groups about disclosure relevant to them only. This study therefore designed six stakeholder-specific versions of the questionnaire (i.e., EC version, EN version, $L A$ version, $H R$ version, SO version, and $P R$ version) for the six broad stakeholder groups identified in the GRI framework (i.e., economic stakeholders, environmental stakeholders, labor stakeholders, human rights stakeholders, society stakeholders, and product stakeholders). Each questionnaire version asked the given stakeholder group to rate the five disclosure types from 0 to 100 by providing specific 
examples for each disclosure type that represented disclosure in the performance category relevant to that version. Additionally, all stakeholder-specific questionnaires provided common examples for each disclosure type for context items in the GRI framework.

Unlike shareholders where a registry is maintained by a firm as a legal requirement, the lack of information about stakeholder composition specific to a firm posed a challenge to the selection of stakeholders surveyed. A firm's management is experientially aware of the stakeholder composition of the firm as they prepare the annual report and the CSR report for corporate stakeholders. Hence, this study contacted corporate executives involved in preparing annual reports and/or CSR reports and requested them to distribute the six questionnaire versions to relevant stakeholder groups of their firms. According to corporate executives' experiential judgments, each stakeholder group was surveyed for the stakeholders' perceptions on the relative preference of different disclosure types of corporate social and environmental disclosures.

\subsubsection{Disclosure item quality}

We ascertained the disclosure quality relating to the importance of $121 \mathrm{GRI}$ items by conducting a stakeholder panel consultation. There has been no previous research that specifically examines the relative importance of GRI reporting items to stakeholders, but rather assumed that all items are of equal value to stakeholders (Clarkson et al., 2011). Reviewing the literature, however, some researchers emphasized the fact that certain disclosure items are more important than others to stakeholders, and suggested that the 
importance weighting of items contributes to enhancing the disclosure relevance (Beattie et al., 2004; Schneider and Samkin, 2008). This study therefore, constituted a stakeholder panel and asked their opinions on the relative importance of disclosure items. This panel comprised 12 various stakeholder members ${ }^{1}$. The panel members were selected from a wide range of stakeholder groups based on their involvement with corporate social and environmental activities, knowledge of what might be included in corporate annual reports and CSR reports, and personal experience. To ensure the effectiveness of the stakeholder panel, each panel member was asked to review the list of $121 \mathrm{GRI}$ items in a questionnaire given to them. For each item, the panel members were asked for their opinions on whether the item should or should not be disclosed and the varying degrees of importance if should be disclosed based on the rating scale from 0 to 4 ( 0 if item should not be disclosed, 1 if item should be disclosed but is of minor importance, 2 if item should be disclosed and is of intermediate importance, 3 if item should be disclosed and is very important, and 4 if item should be essentially disclosed) used by Schneider and Samkin (2008). The relative importance of each item was determined as the mean (or average) score of the 12 panel members' opinions.

The motivation for asking stakeholders' perceptions on disclosure types and disclosure items importance when constructing the SEDI comes from the theoretical underpinning. Stakeholders become the focal point when using stakeholder theory, and the quality

1 (1) A large individual shareholder, (2) a manager of an institutional shareholder, (3) a banking loan manager, (4) a chief officer of a government authority, (5) an academic, (6) an auditor partner, (7) a human resource manager of the firm, (8) an employee representative, (9) a customer representative, (10) a manager of a major supplier, (11) a representative of the local community, and (12) a local media manager. 
measure of disclosure should be relevant to various stakeholders in their decision-making. Although it is easier and less time-consuming to measure the disclosure quality from researchers' perspectives rather than from stakeholders' perspectives, it would not reflect the pragmatic reality that firms make social and environmental disclosures for their stakeholders.

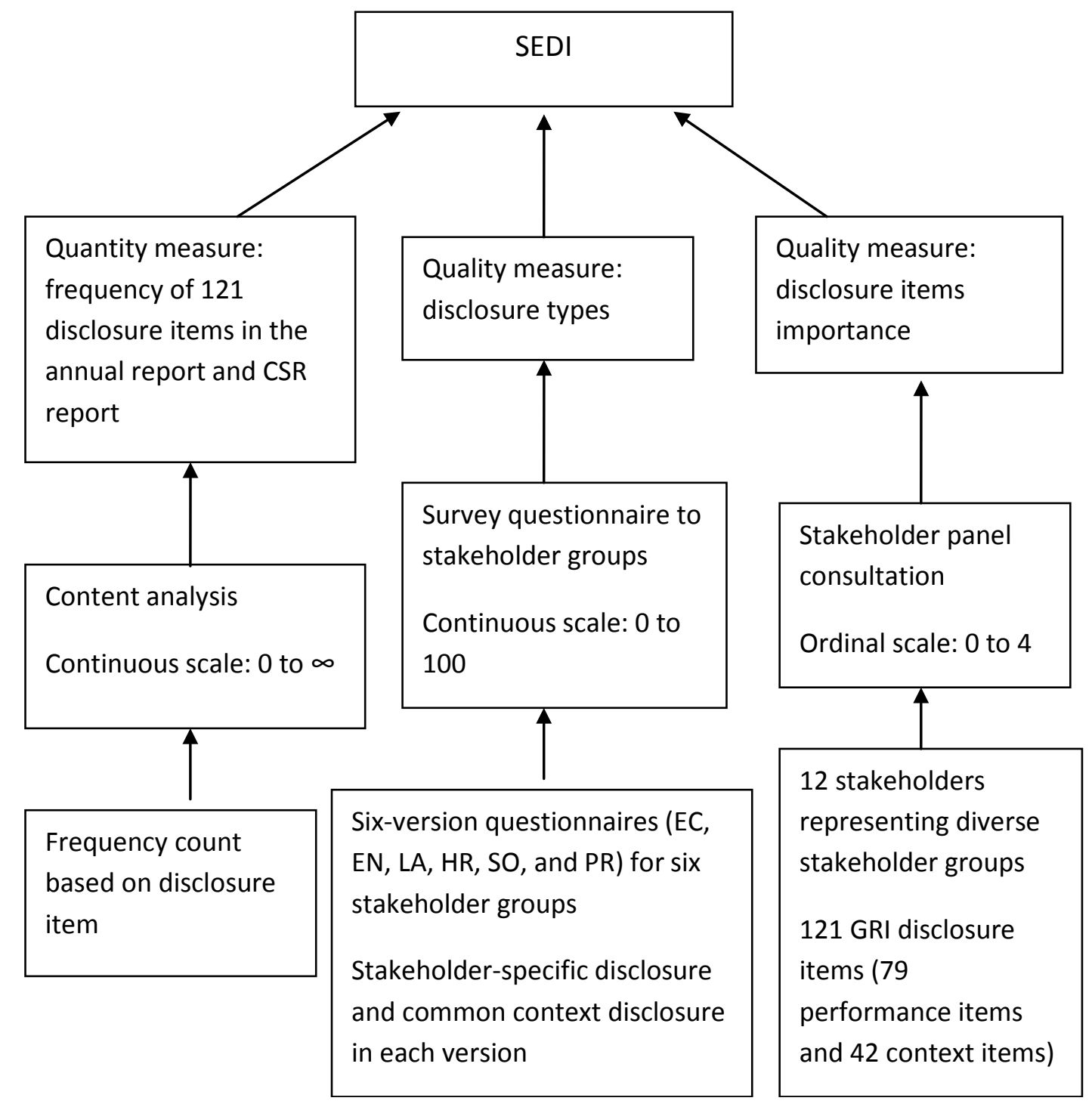

Fig. 2. Social and Environmental Disclosure Index (SEDI) construction 
The stakeholder-driven, three-dimensional social and environmental disclosure index (SEDI) constructed in this study was therefore a product of the three disclosure dimensions for a given firm: disclosure quantity score ${ }^{*}$ disclosure type quality score $*$ disclosure item quality score. When calculating the SEDI of a firm, the quality score of each disclosure type for a given GRI item was multiplied by the disclosure frequency for that disclosure type and then added up for all disclosure types to get the total of that GRI item. This score was multiplied by the importance score of the item to achieve the final disclosure score of the item. The aggregated scores of all 121 items became the SEDI for the given firm.

\subsection{Empirical model}

In light of the above discussion, we empirically examine the influence of various determinants on corporate social and environmental disclosures by employing the following model. The social and environmental disclosure index (SEDI) developed as above was used as a proxy for corporate social and environmental disclosure.

$\mathrm{SEDI}_{i}=\beta_{0}+\beta_{1} \mathrm{CSOE}_{i}+\beta_{2} \mathrm{OWN}_{i}+\beta_{3} \mathrm{LEV}_{\mathrm{i}}+\beta_{4} \mathrm{AUDIT}_{\mathrm{i}}+\beta_{5} \mathrm{SIZE}_{\mathrm{i}}+\beta_{6} \mathrm{FIN}_{\mathrm{i}}+\beta_{7} \mathrm{IND}_{\mathrm{i}}$

$+\beta_{8} X-$ LISTED $_{i}+\varepsilon$

where

$i=1,2, \ldots 100$.

The variables in the model above are defined in Table 2. 
Table 2

Variable Definitions and Measurement

\begin{tabular}{|c|c|c|c|}
\hline Variable & Proxy & Measurement & Data source \\
\hline \multicolumn{4}{|c|}{ Dependent variable } \\
\hline SEDI & $\begin{array}{l}\text { Social and } \\
\text { environmental } \\
\text { disclosure index for } \\
\text { the year } 2008\end{array}$ & $\begin{array}{l}\text { Disclosure quantity * disclosure type } \\
\text { quality * disclosure item quality }\end{array}$ & $\begin{array}{l}\text { Annual } \\
\text { reports, CSR } \\
\text { reports, and } \\
\text { survey }\end{array}$ \\
\hline \multicolumn{4}{|c|}{ Determinants - stakeholders' power } \\
\hline CSOE & Government power & $\begin{array}{l}1 \text { for central state-owned enterprises } \\
\text { (SOEs), and } 0 \text { otherwise }\end{array}$ & $\begin{array}{l}\text { CSMAR } \\
\text { database }\end{array}$ \\
\hline OWN & Shareholder power & $\begin{array}{l}\text { Percentage of shares owned by the } \\
\text { largest shareholder at the end of the } \\
\text { year } 2008\end{array}$ & $\begin{array}{l}\text { CSMAR } \\
\text { database }\end{array}$ \\
\hline LEV & Creditor power & $\begin{array}{l}\text { Total debts/total assets ratio at the end } \\
\text { of the year } 2008\end{array}$ & $\begin{array}{l}\text { CSMAR } \\
\text { database }\end{array}$ \\
\hline AUDIT & $\begin{array}{l}\text { Independent } \\
\text { auditor }\end{array}$ & $\begin{array}{l}1 \text { for firms audited by Big Four audit } \\
\text { firms in the year 2008, and } 0 \text { otherwise }\end{array}$ & Annual reports \\
\hline \multicolumn{4}{|c|}{ Determinants - corporate characteristics } \\
\hline SIZE & Firm size & $\begin{array}{l}\text { Natural logarithm of total revenues for } \\
\text { the year } 2008\end{array}$ & $\begin{array}{l}\text { CSMAR } \\
\text { database }\end{array}$ \\
\hline FIN & $\begin{array}{l}\text { Financial } \\
\text { performance }\end{array}$ & Profit margin ratio for the year 2008 & $\begin{array}{l}\text { CSMAR } \\
\text { database }\end{array}$ \\
\hline IND & $\begin{array}{l}\text { Industry } \\
\text { membership }\end{array}$ & $\begin{array}{l}1 \text { for firms belonging to high-profile industry } \\
\text { (including metals, banking \& insurance, } \\
\text { extractive, construction, telecommunication, } \\
\text { electricity, transportation, oil \& chemical, } \\
\text { and food \& beverage), and } 0 \text { otherwise. }\end{array}$ & $\begin{array}{l}\text { CSMAR } \\
\text { database }\end{array}$ \\
\hline X-LISTED & Overseas listing & $\begin{array}{l}1 \text { for firms cross-listed on other } \\
\text { developed stock markets in the year } \\
2008 \text {, and } 0 \text { otherwise }\end{array}$ & Annual reports \\
\hline
\end{tabular}




\section{Results and analyses}

\subsection{Descriptive analysis for the variables}

The results of the descriptive statistics for SEDI, various disclosure categories based on GRI guidelines, and other continuous variables are presented in Table 3. The dependent variable SEDI ranged from a minimum score of 5172.50 to a maximum score of 33299.16 , with a mean of 12783.86 and a standard deviation of 5253.86, indicating that there was a large variation in social and environmental disclosure among sample firms. The variable that represents creditor power, financial leverage (LEV), had a high mean value of 0.619 , indicating that on average firms were highly geared. The corporate characteristic variable financial performance (FIN) had a low mean value of 0.079 , which might be due to the fact that many firms have been influenced by the global economic crisis of 2008 as these firms earn a high proportion of revenues from international trade. The variable that represents shareholder power in this study, concentrated ownership (OWN), had a minimum of 0.068 and a maximum of 0.864 with a mean of 0.487 and a standard deviation of 0.188 , indicating that firms had varying degrees of shareholder concentration.

For different disclosure categories, information related to Context items and Economic Performance items were the most disclosed, with a mean value of 3924.23 for Context and a mean value of 3643.58 for Economic Performance. The variation in disclosure among sample firms for both Environmental Performance items and Social Performance items was relatively large, with a standard deviation of 1397.93 and 1868.07 , respectively. A minimum score of 0 for Environmental Performance and Human Rights suggests that some firms did 
not disclose any information about their environmental performance and human rights (HR). The HR disclosure is a sensitive aspect for China, as it is often criticized for labor rights issues such as 'sweatshop' production where foreign firms subcontract to China (World Bank, 2004) (see section 5.3: Further analysis - Disclosure at the GRI categories level).

Table 3

Descriptive Statistics for Continuous Variables

\begin{tabular}{|c|c|c|c|c|c|c|}
\hline Variable & Obs. & Mean & Std. dev. & Min. & Max. & Median \\
\hline \multicolumn{7}{|c|}{ Dependent variable - main analysis } \\
\hline SEDI & 100 & 12783.86 & 5253.86 & 5172.50 & 33299.16 & 12034.17 \\
\hline \multicolumn{7}{|c|}{ Dependent variables - additional analyses } \\
\hline Context & 100 & 3924.23 & 1236.27 & 2063.33 & 9105.00 & 3675.00 \\
\hline Economic Performance & 100 & 3643.58 & 1330.53 & 1885.83 & 9932.50 & 3369.17 \\
\hline Environmental Performance & 100 & 1607.12 & 1397.93 & 0 & 7975.83 & 1317.50 \\
\hline Social Performance & 100 & 3608.92 & 1868.07 & 758.33 & 9405.00 & 3020.42 \\
\hline Labor & 100 & 1447.93 & 637.35 & 340.00 & 3511.67 & 1278.33 \\
\hline Human Rights & 100 & 162.10 & 136.06 & 0 & 823.33 & 125.00 \\
\hline Society & 100 & 1424.69 & 1126.17 & 60.00 & 5703.33 & 1048.33 \\
\hline Product Responsibility & 100 & 574.20 & 257.66 & 143.33 & 1600.00 & 552.50 \\
\hline \multicolumn{7}{|c|}{ Determinants - stakeholders' power } \\
\hline OWN & 100 & 0.487 & 0.188 & 0.068 & 0.864 & 0.504 \\
\hline LEV & 100 & 0.619 & 0.193 & 0.177 & 0.968 & 0.626 \\
\hline \multicolumn{7}{|c|}{ Determinants - corporate characteristics } \\
\hline SIZE & 100 & 24.417 & 1.043 & 22.512 & 28.004 & 24.171 \\
\hline FIN & 100 & 0.079 & 0.138 & -0.120 & 0.566 & 0.030 \\
\hline
\end{tabular}




\subsection{Analysis and discussion at SEDI level}

\subsubsection{Correlation matrix}

The results of Pearson correlation for SEDI and all continuous variables tested in the model (1) are reported in Table 4. These correlations indicate that collinearity is not present as the highest correlation coefficient is 0.4732 between OWN and SIZE. Also, the variance inflation factors on these two variables are low (1.63 and 2.12, respectively), which further supports the absence of collinearity. This supports the fact that each predictor represents a unique characteristic and no two variables are statistically too similar.

From Table 4, it is evident that SIZE is positively associated with the dependent variable SEDI. Consistent with previous studies (Cormier and Gordon, 2001; Hackston and Milne, 1996), results of this study indicate that the larger firms made more social and environmental disclosures. As hypothesized, FIN is positively associated with SEDI. This is consistent with Roberts (1992), indicating that firms with better financial performance made more social and environmental disclosures. As for the stakeholder variables, this study found that shareholder concentration and creditor power had no positive correlations with corporate social and environmental disclosures. 
Table 4

Pearson correlation coefficients of SEDI and other continuous variables

\begin{tabular}{|l|l|l|l|l|l|}
\hline & SEDI & OWN & LEV & SIZE & FIN \\
\hline SEDI & 1.000 & & & & \\
\hline OWN & 0.1803 & 1.000 & & & \\
\hline LEV & 0.0026 & -0.1650 & 1.000 & & \\
\hline SIZE & $0.6857^{\mathrm{a}}$ & $0.4732^{\mathrm{a}}$ & 0.0758 & 1.000 & \\
\hline FIN & $0.4286^{\mathrm{a}}$ & $-0.2155^{\mathrm{b}}$ & 0.0810 & 0.1240 & 1.000 \\
\hline
\end{tabular}

${ }^{\text {a }}$ Significance is at the 0.01 level.

${ }^{\mathrm{b}}$ Significance is at the 0.05 level.

\subsubsection{Regression results}

To avoid the problem of heteroscedasticity, ordinary least squares (OLS) regression with heteroscedasticity robust standard errors (White, 1980) was used to test the relationships implicit in model (1). The results for regression are shown in Table 5. 
Table 5

Regression results for SEDI

\begin{tabular}{|c|c|c|c|c|c|c|c|c|c|}
\hline & $\beta_{0}$ & CSOE & OWN & LEV & AUDIT & SIZE & FIN & IND & X-LISTED \\
\hline Coefficient & -62355.32 & 259.27 & -3593.02 & -2746.15 & 594.28 & 3108.05 & 11881.71 & 1810.99 & 242.26 \\
\hline t-statistics & -4.76 & 0.38 & -1.74 & -1.21 & 0.73 & 5.36 & 3.99 & 2.91 & 0.22 \\
\hline$p$-value & 0.000 & 0.705 & 0.085 & 0.229 & 0.470 & 0.000 & 0.000 & 0.005 & 0.823 \\
\hline Hypothesis & & $\mathrm{H} 1$ & $\mathrm{H} 2$ & $\mathrm{H} 3$ & $\mathrm{H} 4$ & H5 & $\mathrm{H} 6$ & $\mathrm{H} 7$ & $\mathrm{H} 8$ \\
\hline Expected sign & & + & - & $+/-$ & + & + & + & + & + \\
\hline $\begin{array}{l}\text { Actual sign and } \\
\text { significance }\end{array}$ & & + & -* & - & + & $+* * *$ & $+* * *$ & $+* * *$ & + \\
\hline
\end{tabular}

$R^{2}=0.6285, F=12.96$, and $N=100$

${ }^{*}$ significant at $p<0.1 ;{ }^{* *}$ significant at $p<0.05 ;{ }^{* \star *}$ significant at $p<0.01$

As indicated in Table 5, hypothesis 5 (H5) is strongly supported in the multivariate results with a significantly positive association between SIZE and SEDI at $p=0.000$. This is consistent with the bivariate result in the correlation matrix (shown in Table 4). Consistent with legitimacy theory, the larger listed Chinese firms disclosed more social and environmental information to demonstrate their legitimacy to the public and relevant stakeholders as a means of ensuring their continued operations. Also, consistent with the bivariate result in the correlation matrix, there is a significantly positive association between FIN and SEDI at $p=0.000$. Therefore, hypothesis $6(\mathrm{H} 6)$ is also strongly supported. Chinese firms with high profitability have sufficient financial capability to undertake costly social responsibility disclosure as argued by Ullman (1985) and need to legitimate firms' activities to 
stakeholders due to greater organizational visibility among stakeholders. Another corporate characteristic variable, industry classification, was found to be significantly $(p=0.005)$ and positively associated with SEDI, thus supporting hypothesis 7 (H7). The significant relationship between industry classification and SEDI provides evidence to support the public pressure perspective of legitimacy theory. It is likely that Chinese listed firms in high-profile industries disclosed more social and environmental information as a response to high consumer visibility and regulatory risk. For instance, specific regulatory documents directed towards polluting industries, such as the Regulations of Environmental Inspection on Companies Accessing to or Refinance on the Stock Market (SEPA, 2003), appeared to have prompted firms in polluting industries to disclose more environmental information than other firms. Similar to firm size and corporate profitability, therefore, industry classification is also a statistically significant determinant of corporate social and environmental disclosure in China. However, the positive association predicted between the variable X-LISTED and SEDI was found to be insignificant in the multivariate results.

As reported in Table 5, stakeholders' power variables (i.e., government [CSOE], creditor [LEV] and auditor [AUDIT]) were not found to have a statistically significant relationship ( $p<$ 0.1) with corporate social and environmental disclosure. The shareholder power (OWN) was found to be negatively associated with SEDI at the $p<0.1$ level, suggesting that controlling for other variables in the regression, shareholder concentration negatively influenced firms' social and environmental disclosures. An explanation for the insignificant result between CSOE and SEDI might be that some central state-owned enterprises have not made a substantially positive response to government recommendations of making social and 
environmental disclosure in published reports. It is implied that the Chinese government and its agencies need to prescribe detailed corporate social and environmental disclosure guidelines and make them mandatory for listed firms because the soft approach of encouraging voluntary disclosure has not been effective (Taylor and Shan, 2007). A possible reason for the insignificant relationship between AUDIT and SEDI might be the fact that auditors paid little attention to corporate social and environmental disclosure practices, especially because these were not required to be audited in most jurisdictions including China.

\subsection{Further analysis - Disclosure at the GRI categories level}

To provide more insights, this study further analyzed the relationships between various determinants and corporate social and environmental disclosures across four broad GRI categories: Context, Economic Performance, Environmental Performance, and Social Performance. The regression was repeated by replacing SEDI in the model (1) with the score of each GRI category as the dependent variable. Similarly, heteroscedasticity robust standard errors (White, 1980) were used in all regressions to ensure that the variances of errors across observations did not follow a consistent pattern. The results for a series of regressions are reported in Table 6. 
Table 6

Regression results for GRI categories

Panel A: Context

\begin{tabular}{|c|c|c|c|c|c|c|c|c|c|}
\hline & $\beta_{0}$ & CSOE & OWN & LEV & AUDIT & SIZE & FIN & IND & X-LISTED \\
\hline Coefficient & -13357.84 & 138.62 & -978.04 & 35.90 & 82.52 & 700.03 & 2963.90 & 330.84 & 215.32 \\
\hline t-statistics & -3.57 & 0.89 & -2.11 & 0.07 & 0.45 & 4.21 & 4.79 & 2.31 & 1.02 \\
\hline$p$-value & 0.001 & 0.376 & 0.038 & 0.945 & 0.650 & 0.000 & 0.000 & 0.023 & 0.312 \\
\hline
\end{tabular}

$\mathrm{R}^{2}=0.6412, \mathrm{~F}=12.52$, and $\mathrm{N}=100$.

Panel B: Economic Performance

\begin{tabular}{|c|c|c|c|c|c|c|c|c|c|}
\hline & $\beta_{0}$ & CSOE & OWN & LEV & AUDIT & SIZE & FIN & IND & X-LISTED \\
\hline Coefficient & -15785.37 & -103.22 & -1307.47 & -746.98 & 178.67 & 821.38 & 2995.64 & 220 & 92.08 \\
\hline t-statistics & -3.63 & -0.53 & -2.48 & -1.13 & 0.79 & 4.28 & 4.02 & 1.30 & 0.37 \\
\hline$p$-value & 0.000 & 0.594 & 0.015 & 0.262 & 0.430 & 0.000 & 0.000 & 0.198 & 0.709 \\
\hline
\end{tabular}

$\mathrm{R}^{2}=0.5948, \mathrm{~F}=9.99$, and $\mathrm{N}=100$.

Panel C: Environmental Performance

\begin{tabular}{|c|c|c|c|c|c|c|c|c|c|}
\hline & $\beta_{0}$ & CSOE & OWN & LEV & AUDIT & SIZE & FIN & IND & X-LISTED \\
\hline Coefficient & -12326.13 & 152.31 & 86.68 & -2486.69 & 11.70 & 608.65 & 449.39 & 782.46 & -229.99 \\
\hline t-statistics & -3.52 & 0.67 & 0.12 & -3.42 & 0.05 & 3.89 & 0.41 & 4.33 & -0.68 \\
\hline$p$-value & 0.001 & 0.506 & 0.902 & 0.001 & 0.960 & 0.000 & 0.679 & 0.000 & 0.500 \\
\hline
\end{tabular}

$\mathrm{R}^{2}=0.4107, \mathrm{~F}=6.82$, and $\mathrm{N}=100$.

Panel D: Social Performance

\begin{tabular}{|c|c|c|c|c|c|c|c|c|c|}
\hline & $\beta_{0}$ & CSOE & OWN & LEV & AUDIT & SIZE & FIN & IND & X-LISTED \\
\hline Coefficient & -20885.98 & 71.56 & -1394.20 & 451.62 & 321.40 & 977.99 & 5472.79 & 477.68 & 164.85 \\
\hline t-statistics & -5.42 & 0.29 & -1.95 & 0.62 & 1.07 & 5.74 & 5.51 & 2.05 & 0.43 \\
\hline$p$-value & 0.000 & 0.771 & 0.054 & 0.535 & 0.289 & 0.000 & 0.000 & 0.044 & 0.668 \\
\hline
\end{tabular}

$\mathrm{R}^{2}=0.6603, \mathrm{~F}=18.83$, and $\mathrm{N}=100$.

As shown in Table 6, similar to SEDI, the results for the Context category indicate that SIZE,

FIN, and IND are all significantly and positively associated with Context-related disclosure. 
Further, OWN was found to be significantly and negatively associated with Context-related disclosure. This result suggests that less concentrated ownership encouraged management to disclose the overall context information for understanding corporate performance, such as corporate strategy, profile, and governance.

Similar to Context, the results for the Economic Performance category also indicate a significantly negative association between shareholder concentration and economic performance, suggesting that shareholder dispersion was likely to motivate management to disclose information about corporate economic performance. However, the positive association between industry and economic performance is insignificant in this regression.

The results for the Environmental Performance category are substantially different from the results obtained from the main model. A significantly negative association was found between LEV and environmental performance, which suggests that firms with low leverage disclosed more environmental information as a proactive measure to present the firm as a responsible corporate citizen and to receive a favorable assessment of their financial risk by creditors. This result may also be related to the Green Credit policy ${ }^{2}$ implemented by many Chinese banks (SEPA, PBC \& CBRC, 2007). Firms in demand of credit proactively disclosed environmental information so as to gain green loans for their operations. The relationship between corporate profitability and environmental disclosure was found to be insignificant, which means that firms with higher profitability failed to disclose more environmental

\footnotetext{
${ }^{2}$ A policy requires commercial banks, when reviewing applications for bank credit, to consider whether the applying business has followed environmental laws and regulations. Violators have no chance to obtain approval, while 'green' businesses get favourable treatment in this regard.
} 
information.

Finally, the results for the Social Performance category are similar to the results for SEDI in the main model, indicating that a statistically significant and positive association with social performance disclosure was found for firm size, profitability, and industry respectively; and a significantly negative association between social performance disclosure and concentrated ownership.

As indicated above, the results of GRI categories do not relate well with the results of SEDI. SEDI presents the overall social and environmental disclosure of a firm. When targeting a particular aspect of corporate social and environmental disclosure (e.g., environmental performance), some determinants (e.g., creditor) become significant because they paid more attention to that particular aspect.

\section{Conclusions}

This study presents an up-to-date investigation into corporate social and environmental disclosure practices within the legitimacy and stakeholder frameworks in the context of China. The empirical results provide important insights into the influence of stakeholders' power and corporate characteristics on corporate social and environmental disclosure practices of socially responsible Chinese listed firms. Corporate characteristics, such as firm size, profitability, and industry classification, are all significant factors influencing corporate social and environmental disclosure. Consistent with legitimacy theory, those firms that are 
more likely to be subject to public scrutiny, such as larger firms and firms in high-profile industries, disclosed more social and environmental information to meet the expectations of the public. The pressures from various stakeholders, like government, creditors, and auditors tested in this study, generally appear to be weak in China at present. However, along with the increase in the stakeholders' concerns about corporate social responsibility behaviors, shareholders have influenced firms' social and environmental disclosures; and creditors have influenced firms' disclosures related to their environmental performance. According to stakeholder theory, those firms that seek to gain or maintain the support of particular powerful stakeholders have begun to adopt a disclosure strategy.

This study also provides us with several unexpected but insightful results. For instance, Chinese listed firms with central state ownership were encouraged to make social and environmental disclosure as per the SASAC recommendations, but these firms do not show a substantial difference in social and environmental disclosure compared with other Chinese listed firms. The involvement of the Big Four in the financial audit has also made no substantial difference in corporate social and environmental disclosure. Such findings provide practical implications for Chinese policymakers and other relevant stakeholders. Although the Chinese government and its agencies, as both regulator and facilitator, have issued regulations and guidelines in promoting firms' social and environmental activities and disclosure, ambiguity and uncertainty within governmental regulations and guidelines have led to non-comparable disclosure practices among firms. Therefore, the Chinese government needs to make continuous efforts by providing more detailed guidance regarding the content and extent of social and environmental disclosure to assist firms to 
communicate their social and environmental activities effectively to regulatory bodies and other stakeholders. In the future, audit firms should be encouraged to provide reasonable assurance for firms' social and environmental disclosures in their annual reports and CSR reports.

This study makes a contribution to the social and environmental accounting literature by expanding the scope of extant research on corporate social and environmental disclosure to the context of a developing nation, China. This study also makes a methodological contribution to the literature by constructing a stakeholder-driven, three-dimensional social and environmental disclosure index, which comprises a quantity dimension and two quality dimensions: disclosure types and disclosure items.

However, findings of this study must be interpreted with considering the following limitations. First, owing to the manual collection of disclosure data and a labor-intensive latent content analysis process, a relatively small sample was used, which may limit the application of the findings to firms outside the social responsibility ranking list. Second, despite extensive efforts made regarding the choice of determinants and the development of accurate proxies for various variables, subjectivity was inevitable. Third, it is also acknowledged that the single-year data used for testing the relationships hypothesized in this study may restrict the generalization of findings. Fourth, this study looks into the extent of social and environmental disclosure rather than the existence of disclosure, as the sample comprised socially responsible firms engaging in social and environmental disclosure. The 
findings of this study however provide a springboard for further research. Future studies may consider other potential determinants and examine the association between them and corporate social and environmental disclosure on a longitudinal basis. Another suggestion is to compare and contrast findings between firms on and outside the social responsibility ranking list. 


\section{References}

Ahmad, Z., Hassan, S., Mohammad, J., 2003. Determinants of environmental reporting in Malaysia. International Journal of Business Studies 11(1), 69-90.

Beattie, V., Mclnnes, B., Fearnley, S., 2004. A methodology for analysing and evaluating narratives in annual reports: a comprehensive descriptive profile and metrics for disclosure quality attributes. Accounting Forum 28(3), 205-236.

Brace, I., 2004. Questionnaire Design: How to Plan, Structure and Write Survey Material for Effective Market Research. Kogan Page, London.

Branco, M.C., Rodrigues, L.L., 2008. Factors influencing social responsibility disclosure by Portuguese companies. Journal of Business Ethics 83(4), 685-701.

China Securities Journal, 2009. 290 Listed Firms Disclose Corporate Social Responsibility Reports. http://www.cs.com.cn/ssgs/02/200905/t20090511 1891772.html (accessed 01.09.09).

Cho, C.H., 2009. Legitimation strategies used in response to environmental disaster: $A$ French case study of Total SA's Erika and AZF incidents. European Accounting Review 18(1), 33-62.

Choi, J.S., 1999. An investigation of the initial voluntary environmental disclosures made in Korean semi-annual financial reports. Pacific Accounting Review 11(1), 73-102.

Clarkson, P.M., Li, Y., Richardson, G.D., Vasvari, F.P., 2008. Revisiting the relation between environmental performance and environmental disclosure: an empirical analysis. Accounting, Organizations and Society 33(4/5), 303-327.

Clarkson, P.M., Overell, M.B., Chapple, L., 2011. Environmental reporting and its relation to corporate environmental performance. ABACUS 47(1), 27-60.

Cormier, D., Gordon, I.M., 2001. An examination of social and environmental reporting strategies. Accounting, Auditing \& Accountability Journal 14(5), 587-616.

Cormier, D., Magnan, M., 1999. Corporate environmental disclosure strategies: determinants, costs and benefits. Journal of Accounting, Auditing and Finance 14(4), 429451.

Cormier, D., Magnan, M., 2003. Environmental reporting management: a continental European perspective. Journal of Accounting and Public Policy 22, 43-62. 
Cormier, D., Gordon, I.M., Magnan, M., 2004. Corporate environmental disclosure: contrasting management's perceptions with reality. Journal of Business Ethics 49(2), 143-165.

Cowen, S., Ferreri, L., Parker, L., 1987. The impact of corporate characteristics on social responsibility disclosure: a typology and frequency based results. Accounting, Organizations and Society 12(2), 111-122.

Craswell, A., Taylor, S., 1992. Discretionary disclosure of reserves by oil and gas companies: an economic analysis. Journal of Business Finance and Accounting 19(2), 295-308.

DeAngelo, L., 1981. Auditor size and quality. Journal of Accounting and Economics 3(3), 183-199.

Deegan, C., 2002. The legitimising effect of social and environmental disclosures - a theoretical foundation. Accounting, Auditing \& Accountability Journal 15(3), 282-311.

Deegan, C., Blomquist, C., 2006. Stakeholder influence on corporate reporting: an exploration of the interaction between WWF-Australia and the Australian minerals industry. Accounting, Organizations and Society 31, 343-372.

Deegan, C., Rankin, M., 1997. The materiality of environmental information to users of annual reports. Accounting, Auditing \&Accountability Journal 10(4), 562-583.

Deegan, C., Rankin, M., Tobin, J., 2002. An examination of the corporate social and environmental disclosures of BHP from 1983-1997: a test of legitimacy theory. Accounting, Auditing \& Accountability Journal 15(3), 312-343.

Dierkes, M., Preston, L.E., 1977. Corporate social accounting and reporting for the physical environment: a critical review and implementation proposal. Accounting, Organisations and Society 2(1), 3-22.

Freeman, R., 1984. Strategic Management: A Stakeholder Approach. Pitman, Marshfield.

Frost, G., Jones, S., Loftus, J., Van Der Laan, S., 2005. A survey of sustainability reporting practices of Australian reporting entities. Australian Accounting Review 15(1), 89-96.

Garcia-Sanchez, I., Frias-Aceituno, J., Rodriguez-Dominguez, L., 2013. Determinants of corporate social disclosure in Spanish local governments. Journal of Cleaner Production 39, 60-72.

Global Reporting Initiative (GRI), 2006. Sustainability Reporting Guidelines. http://www.globalreporting.org (accessed 28.08.09). 
Gray, R., Kouhy, R., Laver, S., 1995. Corporate social and environmental reporting: a review of the literature and a longitudinal study of UK disclosure. Accounting, Auditing \& Accountability Journal 8(2), 47-77.

Guo, P.Y., 2005. Corporate Environmental Reporting and Disclosure in China. CSR Asia, Beijing.

Hackston, D., Milne, M.J., 1996. Some determinants of social and environmental disclosures in New Zealand companies. Accounting, Auditing \& Accountability Journal 9(1), 77-108.

Hart, S., 1995. A natural resource-based view of the firm. Academy of Management Review 20(4), 986-1014.

Keim, G., 1978. Managerial behaviour and the social responsibilities debate: goals versus constraints. Academy of Management Journal 21, 57-68.

Laksmana, I., Yang, Y., 2009. Corporate citizenship and earnings attributes. Advances in Accounting 25, 40-48.

Lindblom, C.K., 1994. The implications of organizational legitimacy for corporate social performance and disclosure. Critical Perspectives on Accounting Conference, New York, NY.

Liu, X., Anbumozhi, V., 2009. Determinant factors of corporate environmental information disclosure: an empirical study of Chinese listed companies. Journal of Cleaner Production 17, 593-600.

Mahadeo, J., Hanuman, V., Oogarah-Soobaroyen, T., 2011. A longitudinal study of corporate social disclosures in a developing economy. Journal of Business Ethics 104 (4), 545-558.

Neu, D., Warsame, H., Pedwell, K., 1998. Managing public impressions: environmental disclosures in annual reports. Accounting, Organizations and Society 23(3), 265-282.

O'Donovan, G., 2002. Environmental disclosures in the annual report: extending the applicability and predictive power of legitimacy theory. Accounting, Auditing \& Accountability Journal 15(3), 344-371.

Parker, L.D., 2005. Social and environmental accountability research: a view from the commentary box. Accounting, Auditing \& Accountability Journal 18(6), 842-860.

Patten, D.M., 1991. Exposure, legitimacy and social disclosure. Journal of Accounting and Public Policy 10(3), 297-308.

Roberts, R.W., 1992. Determinants of corporate social responsibility disclosure: an application of stakeholder theory. Accounting, Organisations and Society 17(6), 595-612.

Schneider, A., Samkin, G., 2008. Intellectual capital reporting by the New Zealand local government sector. Journal of Intellectual Capital 9(3), 456-486. 
State-owned Assets Supervision and Administration Commission of the State Council (SASAC), 2008. Guidelines on Central State-owned Enterprises Fulfilling Social Responsibilities. http://www.sasac.gov.cn (accessed 02.09.09) (in Chinese).

SEPA (State Environmental Protection Administration), 2003. Regulations of Environmental Inspection on Companies Accessing to or Refinancing from the Stock Market. http://www.sepa.gov.cn (accessed 02.09.09) (in Chinese).

SEPA (State Environmental Protection Administration), PBC (People's Bank of China), CBRC (China Banking Regulatory Commission), 2007. Notes on Reducing Loan Risk by Enforcing Environmental Protection Policies and Regulations. http://www.sepa.gov.cn (accessed 02.09.2009) (in Chinese).

Taylor, D., Shan, Y.G., 2007. What drives the fledging practice of social and environmental reporting by Chinese companies listed in Hong Kong. Accounting, Accountability \& Performance 13(2), 55-86.

Toms, J.S., 2002. Firm resources, quality signals and the determinants of corporate environmental reputation: some UK evidence. British Accounting Review 34(3), 257-282.

Ullmann, A.E., 1985. Data in search of a theory: a critical examination of the relationships among social performance, social disclosure and economic performance of US firms. Academy of Management Review 10(3), 540-557.

Unerman, J., 2007. Stakeholder engagement and dialogue, in Unerman, J., Bebbington, J. and O'Dwyer, B. (eds), Sustainability Accounting and Accountability. Routledge, New York, 86-103.

United Nations Economic and Social Commission for Asia and the Pacific (UNESCAP), 2010. Creating Business and Social Value: the Asian Way to Integrate CSR into Business Strategies (Studies in Trade and Investment 68). United Nations publication, New York.

Van Staden, C.J., Hooks, J., 2007. A comprehensive comparison of corporate environmental reporting and responsiveness. British Accounting Review 39, 197-210.

Wallace, R.S.O., Naser, K., Mora, A., 1994. The relationship between the comprehensiveness of corporate annual reports and firm characteristics in Spain. Accounting and Business Research 25(97), 41-53.

White, H., 1980. A heteroscedasticity-consistent covariance matrix estimator and a direct test for heteroscedasticity. Econometrica 48, 817-838.

Wiseman, J., 1982. An evaluation of environmental disclosures made in corporate annual reports. Accounting, Organizations and Society 7(1), 53-63. 
Woodward, D., Edwards, P., Birkin, F., 2001. Some evidence on executives' views of corporate social responsibility. British Accounting Review 33(3), 357-397.

World Bank, 2004. Opportunities and Obstacles for Corporate Social Responsibility in Developing Countries. World Bank, Washington, DC.

Xiao, S.F., Hu, W., 2005. A study on the environmental information disclosure system of Chinese enterprises. Accounting Research 3, 47-52 (in Chinese).

Zeng, S.X., Xu, X.D., Dong, Z.Y., Tam, V., 2010. Towards corporate environmental information disclosure: an empirical study in China. Journal of Cleaner Production 18, 1142-1148. 